\title{
Formation Process of Interpenetration Polymer Networking Composite Base on Poly Composite Polyurethane-Natural Rubber Assisted Montmorillonite as A Filler
}

\author{
TAMRIN $^{1, \star}$, RIKSON SIBURIAN ${ }^{1,2, * \star}$ and BARITA ARITONANG ${ }^{3,4}$ \\ ${ }^{1}$ Chemistry Department-Faculty of Mathematic and Natural Sciences, University of \\ Sumatera Utara-Medan-Indonesia. \\ ${ }^{2}$ Nanomedicine Center and Stem Cell Center, University of Sumatera Utara, Indonesia. \\ ${ }^{3}$ Chemistry-Post Graduated, University of Sumatera Utara JL. Biotekhnologi, No.1 Medan, \\ P.Bulan, Kampus USU (20155). \\ ${ }^{4}$ Chemistry Department-Universitas Sari Mutiara, Medan. \\ ${ }^{*}$ Corresponding author E-mail: Thamrinusu@gmail.com
}

http://dx.doi.org/10.13005/ojc/330446

(Received: February 23, 2017; Accepted: June 23, 2017)

\begin{abstract}
The formation process of Interpenetration Polymer Network (IPN) base on poly blend polyurethane (PU)-SIR-5 Natural Rubber (NR) which assisted montmorillonite (MMT) as a filler was carried out. The PU was synthesized by mixing polypropylene glycol and toluene diisocyanates (mole ratio 2: 1). NR was vulcanised by adding stearic Acid, zinc oxide, MBTS and sulfur, respectively. PU was mixed with NR at $140^{\circ} \mathrm{C}$ to generate IPN PU-NR. Then, IPN PU-NR- MMT composite may be produced by adding MMT. The IPN PU-NR-MMT composite was characterized by Tensile Strength Test, Water Absorption Test, SEM, FTIR and DSC, respectively. The results showed that a mixture of IPN composites increased with increasing MMT and its good elongation. Mechanical properties, physical and IPN composite morphology is influenced by the amount of MMT. It causes there is a cross linking each other at the bond interface.
\end{abstract}

Keywords: Interpenetrating polymer network (IPN), SIR-5 Natural Rubber (NR),

Polyurethanes (PU), Montmorillonite (MMT)

\section{INTRODUCTION}

Interpenetrating Polymer Network (IPN) was made by using cross linking material which was synthesized with condensation, addision and propagation reactions as well as used several monomers. Then, monomer was polymerized and cross linked. IPN is made base on several polymers where it is difficult to well mixture and result two phase (heterogen phase). Therefore, many researchers solve this problem by using IPN. This way was expected to generate the better material properties than the mixing polymer method base on large temperature and production of polymer. 
Vivek (2013) has reported the synthesize of IPN by using sequential method with transesterification reaction. It showed that the thermal stability of IPN material is better than the pure polystyrene. The properties of IPN which was produced by (polyurethane $(50 \% \mathrm{w} / \mathrm{w}$ ) : poly acrylic $\left(50 \% \mathrm{w} /{ }_{w}\right)$ has a good mechanical and thermal properties but the hardness property is worst (Marinovic, 2010). Shoubing (2011) reported that IPN composite showed its thermal decomposition increase and may be used as well as waving mute. IPN may be produced base on composites of poly (3, 4-etylendiocsitiopene), Nitril Butadiene, and oxide polyetilene. The data showed the IPN has the high flexibility (Laurent, 2014). Nicolas (2014) also reported IPN was synthesized by mixing polyetilenoxide and Nitril Butadiene Rubber. Pseudo-IPN was a polymer networking where was synthesized from mixing 2,4-toluene biisocianat and 1,4-butanadiol. It showed the elastomeric property (Amrollahi, 2011). Therefore, synthesize of IPN is needed.

In this paper, we reported synthesize of IPN with mixing Natural Rubber (NR) and polyuretan under condition solvent of toluene biisosianat (TBI) and glycol polypropylene. The IPN composite may assist with adding monmorillonit (MMT). Also the characterizations of IPN are reported (Tensile Strength Test, Water Absorption Test, SEM, FTIR and DSC, respectively). The important point of this paper we would like to clarify formation process of IPN composite base on polyurethanes, natural rubber and monmorillonit materials.

\section{MATERIAL AND METHOD}

\section{Synthesize IPN}

Synthesize IPN was carried out by using several steps namely: i) Natural rubber (90 phr) which have been masticated (see in supporting information) was added stearic acid (2 phr). It was mixed in internal mixer at $40^{\circ} \mathrm{C}$ for 5 minutes; ii) Adding $1 \mathrm{phr}$ $\mathrm{ZnO}$ and mixed for 1 menit; iii) Adding 1 phr MBTS and stirred for 5 minutes; iv) Then, 0,5 phr sulphur was mixed and stirred for 1 hour; v) Subsequently, adding 10 phr polyurethane and stirred for 20 minutes; vi) Finally, composite was compressed by using hot compressor as well as reference of ASTM D638 Tipe V. The molecule weight of natural rubber is shown in Table 1S (see in supporting information). The ratio amount of PU and NR are shown in Table 2S (see in supporting information).

\section{Preparation of IPN composite with Montmorillonit as Filler}

82 phr NR-PU was put in internal mixer and stirred at $\mathrm{T}=140^{\circ} \mathrm{C}$. Then, it was added $18 \mathrm{phr}$ MMT and stirred for 15 minutes. Finally, composite was compressed by using hot compressor as reference at ASTM D638 tipe V under conditions $\mathrm{T}=140{ }^{\circ} \mathrm{C}$ for 15 minutes. Ratio amount of $\mathrm{Pu}$ : NR : MMT was shown in Table $3 S$ (see in supporting information).

\section{Characterization of IPN Composite}

IPN composite was characterized by using tensile tester (see in supporting information), Scanning Electron Microscope (SEM), and Differential Scanning Calorimeter (DSC).

\section{RESULT AND DISCUSSION}

\section{FTIR Data}

Hasil Analisa Gugus Fungsi Poliuretan dari Toluena Diisosianat dan Polipropilena Glikol

Formation of IPN composite on polyurethane was characterized by using FTIR data (Figure 1).

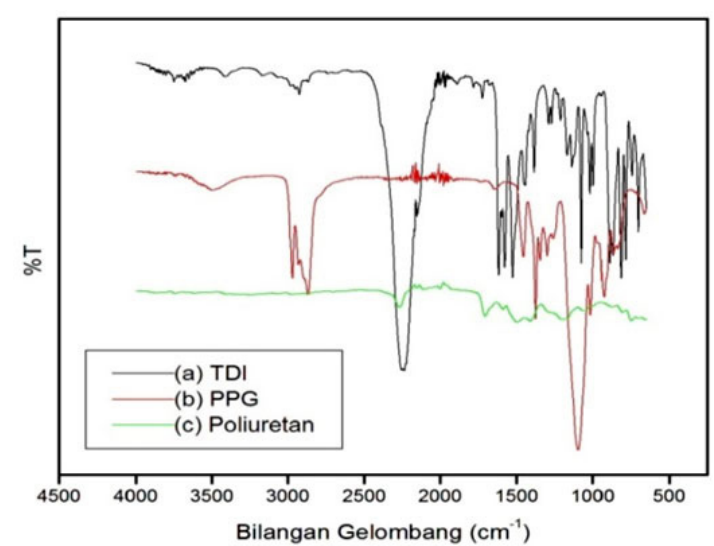

Fig. 1: FTIR Data of Toluene Diisocyanat (TDI), Polypropylene Glycol (PPG) and Polyurethane (PU)

FTIR data show adsorption band at 3299.92 $\mathrm{cm}^{-1}$, indicating gugus $\mathrm{N}-\mathrm{H}$ functional group and wave number $\left(1713,14 \mathrm{~cm}^{-1}\right)$ appears as well as $\mathrm{C}=\mathrm{O}$ (see supporting information Table $4 \mathrm{~S}$ ) . It is a 
character of urethane from polyurethane. In addition, the FTIR spectrum of polyurethane $\left(2270.77 \mathrm{~cm}^{-1}\right)$ is changed. It indicates polymerization occurs due to isocyanides group $(\mathrm{N}=\mathrm{C}=\mathrm{O})$ decreases. The weak peak appears at $2270.7 \mathrm{~cm}^{-1}$, it means isocyanides still remains and reacts with polyol. Formation polyurethane is indicated by changing of functional group as well as reaction between TDI and PGG (see supporting information Table $5 \mathrm{~S}$ and $6 \mathrm{~S}$ ), indicating polyurethane has good properties. Therefore, it may be used to synthesize IPN composite.

\section{Mechanic Properties}

Mechanic tests (Universal System Mechine test) are carried out to understand well about effect of IPN with and without monmorillonit. Mechanic test data of IPN NR - PU (without montmorillonit) may be seen in Table 1.

Table 1 show the ratio of NR: PU (phr) $80: 20$ is the best among the others. The tensile strain, strength and modulus of elasticity increase with adding $20 \mathrm{phr}$ polyurethane. In contrast, they will gradually decrease when PU amount is decreasing. It means amount of PU is very important to assist homogeny and compatible between NR and PU at IPN as well as to improve mechanic property. On the other hand, too much amount of PU will affect compatibility of NR and PU on IPN composite. It is consistent at ratio of $\mathrm{PU}(50,60$ and 70$)$ where their tensile strength is zero. It means amount of $\mathrm{PU}$ is very important to produce IPN compatible and

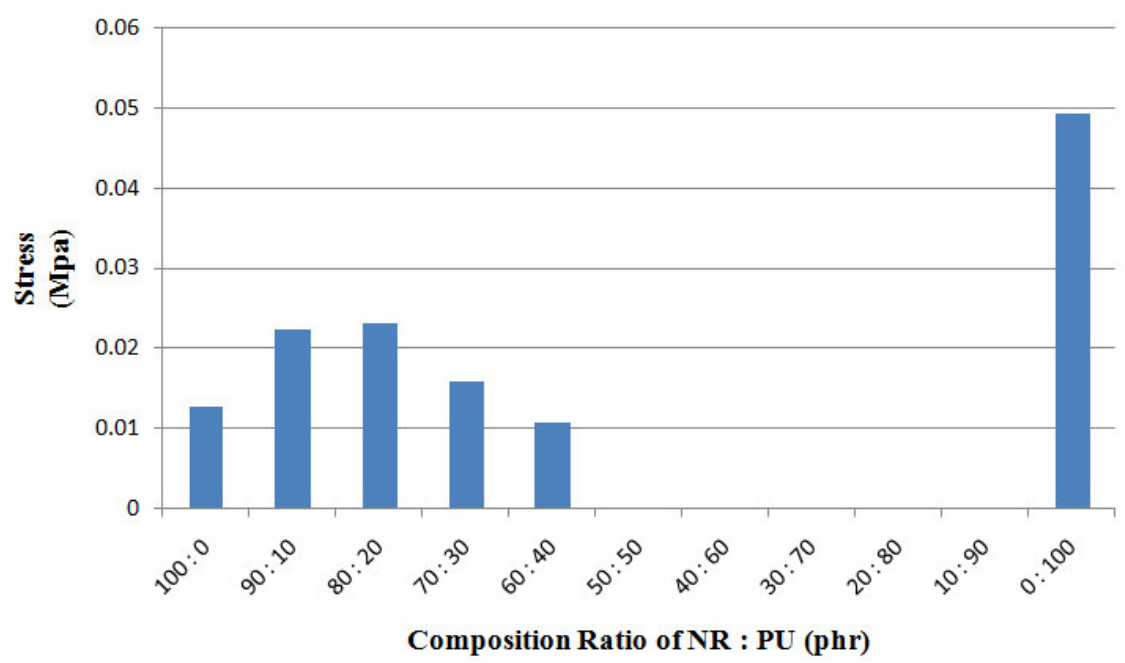

Fig. 2: Stress number versus Composition Ratio (Without Montmorillonit)

Table 1: Mechanic test of IPN NR - PU

\begin{tabular}{llll}
\hline $\begin{array}{l}\text { Ratio of NR : } \\
\text { PU(phr) }\end{array}$ & $\begin{array}{l}\text { Stress }\left(\times \mathbf{1 0}^{-3}\right) \\
(\mathbf{M p a})\end{array}$ & Strain(\%) & $\begin{array}{l}\text { Modulus of Elastisity } \\
\left(\mathbf{\times 1 0 ^ { - 3 }}\right) \mathbf{( M p a )}\end{array}$ \\
\hline $100: 0$ & 12,56 & 65,13 & 19,28 \\
$90: 10$ & 22,22 & 82,02 & 27,09 \\
$80: 20$ & 23,11 & 96,21 & 24,02 \\
$70: 30$ & 15,71 & 86,84 & 18,09 \\
$60: 40$ & 10,68 & 37,24 & 28,68 \\
$50: 50$ & 0 & 0 & 0 \\
$40: 60$ & 0 & 0 & 0 \\
$30: 70$ & 0 & 0 & 0 \\
$20: 80$ & - & - & - \\
$10: 90$ & - & - & \\
$0: 100$ & 49,25 & 5,53 & 890,60 \\
\hline
\end{tabular}


improving the mechanic properties of IPN composite. Furthermore, the stress and strain strength of ration NR: PU are shown in Figure 2 and 3, respectively.

The stress tensile number of NR : PU composite is lower than the $100 \%$ of PU. It causes distribution of phase between NR and PU is weak thereby stress number of NR : PU composite will be go down. For strain number, NR : PU composite is higher than pristine NR (without PU). It is caused PU assists to increase strain tensile of NR due to PU contributes to increase interfacial bonding between NR and PU for IPN composite.

Then, montmorillonit effect for IPN composite beyond mechanic properties is shown in Table 2 .

The best composite base on mechanic properties is NR-PU : MMT $(74: 26)$. Stress and strain tensile of IPN composite with montmorillonit $26 \mathrm{phr}$ as well as filler increase due to interfacial bonding between NR-PU and MMU increase. It also may cause transition of pressure which generate good stress tensile. The other reasons, presence of montmorillonit contribute to homogenize of composite in term of synchronize phase. It means compatibility of composite increase. Briefly, it may be seen in Figures 4 and 5.

Figures 4 and 5 show that composition ratio of NR-PU : MMT $82: 18 \mathrm{phr}$ has the smallest of stress tensile number $\left(6,48 \times 10^{-3} \mathrm{Mpa}\right)$, strain tensile number $(65,78 \%)$ and Modulus of Elastisity $\left(9,85 \times 10^{-3} \mathrm{Mpa}\right)$ among the others. It causes amount of montmorillonit is too small. It will affect pressure transition, heterogenic phase will occur and composite will be incompatible.

Table 2: Mechanic test of IPN Composite (With Montmorillonit)

\begin{tabular}{llll}
\hline Ratio of NR-PU : & $\begin{array}{l}\text { Stress }\left(\mathbf{x} \mathbf{1 0}^{-3}\right) \\
\text { (Mpa) }\end{array}$ & $\begin{array}{l}\text { Strain(\%) } \\
\text { MMT(phr) }\end{array}$ & $\begin{array}{l}\text { Modulus of } \\
\text { Elastisity } \\
\left(\mathbf{1 0 ^ { - 3 }}\right)(\mathbf{M p a})\end{array}$ \\
\hline $82: 18$ & 6,48 & 65,78 & 9,85 \\
$80: 20$ & 9,98 & 92,97 & 10,73 \\
$78: 22$ & 10,67 & 109,89 & 9,71 \\
$76: 24$ & 12,31 & 124,58 & 9,88 \\
$74: 26$ & 18,92 & 150,14 & 12,60 \\
$72: 28$ & 14,13 & 140,00 & 10,09 \\
$70: 30$ & 6,92 & 107,29 & 6,45 \\
$68: 32$ & 6,00 & 96,94 & 6,19 \\
\hline
\end{tabular}

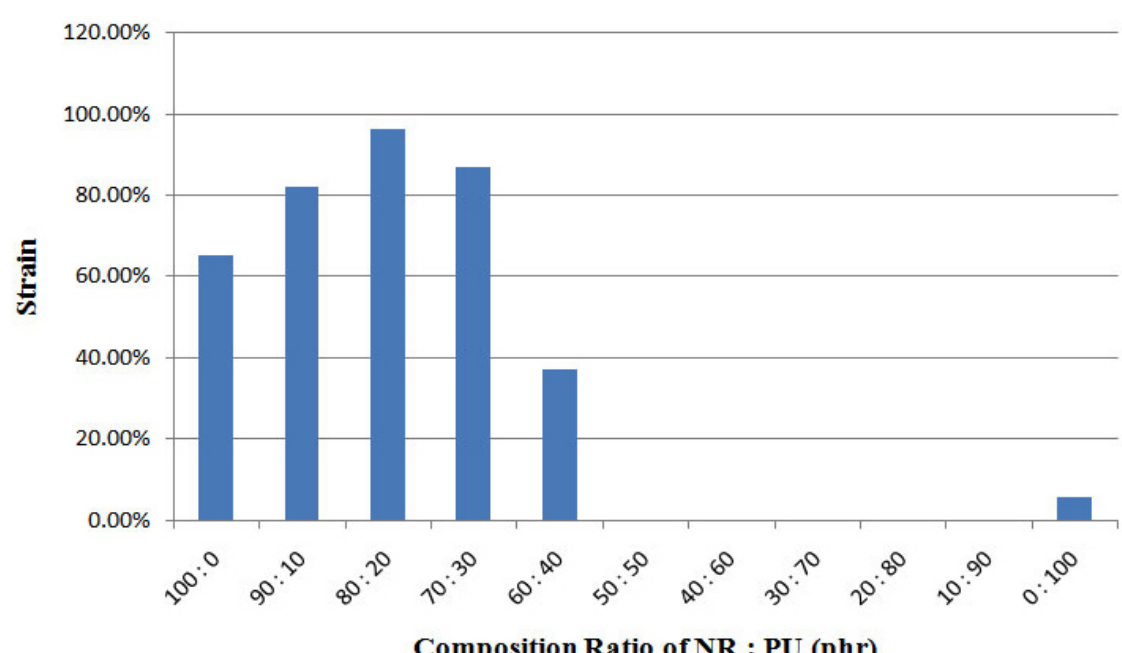

Fig. 3: Strain number versus Composition Ratio (Without Montmorillonit) 


\section{SEM Analysis}

The morphology of IPN composite is characterized by using SEM-EDS (Figures 6 and 7).

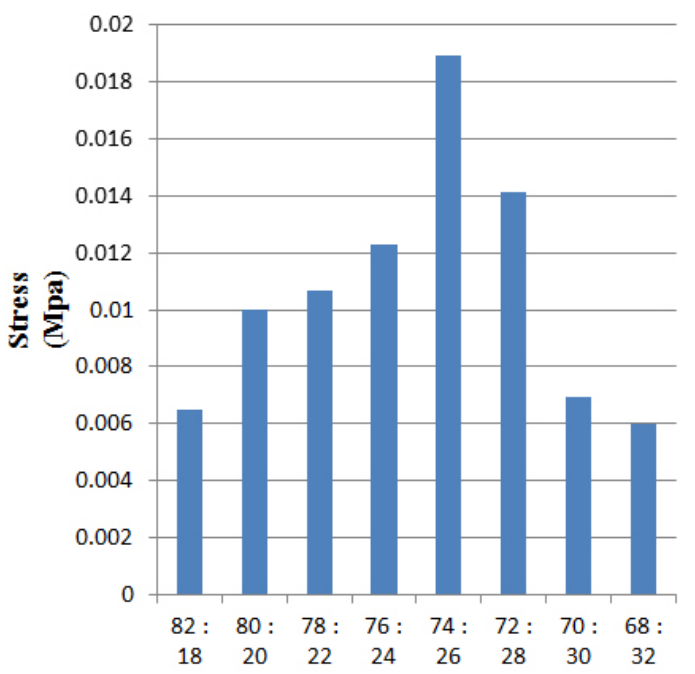

Composition Ratio of NR-PU : MMT (phr)

Fig. 4: Stress number of IPN Composite versus Composition Ratio (With Montmorillonit)
Figure 6 show IPN composite's shape is homogeny among natural rubber, polyurethane and montmorillonit. Filler may affect stress and strain tensile due to there is surface interface binding. Surface of IPN composite is void and matrix cracking. It is caused effect of strain and stress tensile (Figure 6). There is a rapture and rigid area, indicating by homogeny of matrix phase. In addition, particles of montmorillonit are be well dispersed and inserted into natural rubber and polyurethane composite. Fortunately, montmorillonit particles which are be well inserted into NR-PU has not be destructed along composite process. It probes that IPN formation is exist. In owing to IPN networking just occur at interface binding.

Image of IPN composite with adding MMT (82 : $18 \mathrm{phr}$ ) is shown in Figure 7. We may see decreasing effect of MMT to IPN composite.

Figure 7 show that decreasing amount of MMT will cause stress tensile decreases. It may explain that dispersion of MMT is non-homogeny. Therefore, matrix cannot bind MMT fluently thereby interface between NR-PU and montmorillonit is

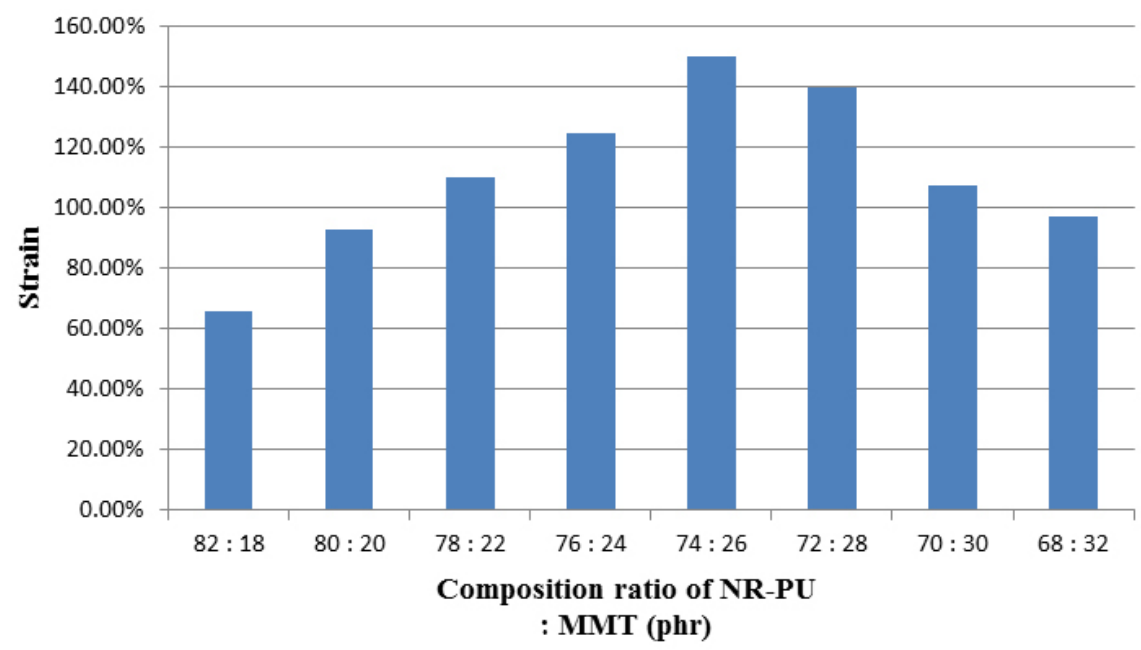

Fig. 5: Strain number of IPN Composite versus Composition Ratio (With Montmorillonit)

Table 3: Thermal analysis of IPN NR-PU composite

\begin{tabular}{lccl}
\hline Materials & $\mathbf{T g}\left({ }^{\circ} \mathbf{C}\right)$ & $\operatorname{Tm}\left({ }^{\circ} \mathbf{C}\right)$ & Decomposition $\left({ }^{\circ} \mathbf{C}\right)$ \\
\hline NR : PU $(80: 20)$ & 108,38 & 343,00 & 397,63 \\
NR-PU : MMT $(74: 26)$ & 122,29 & 363,53 & 391,78 \\
NR-PU : MMT $(82: 18)$ & 120,89 & 340,30 & 344,19 \\
\hline
\end{tabular}


weak. That is consistent with debonding at rapture area also decrease and there is matrix cracking. Debonding occurs when adding montmorillonit decrease. The weak interaction causes stress tensile of IPN composite will be decrease as amount of filler decreasing effect (Savetiana, 2013). At low concentration of filler, the IPN composite rigidity is weak. It is caused chain formation of composite disperse non-homogeny (Jacob, J. 2010).

In this research, we found that optimize amount of montmorillonit on NR : PU matrix will produce good IPN composite base on mechanic

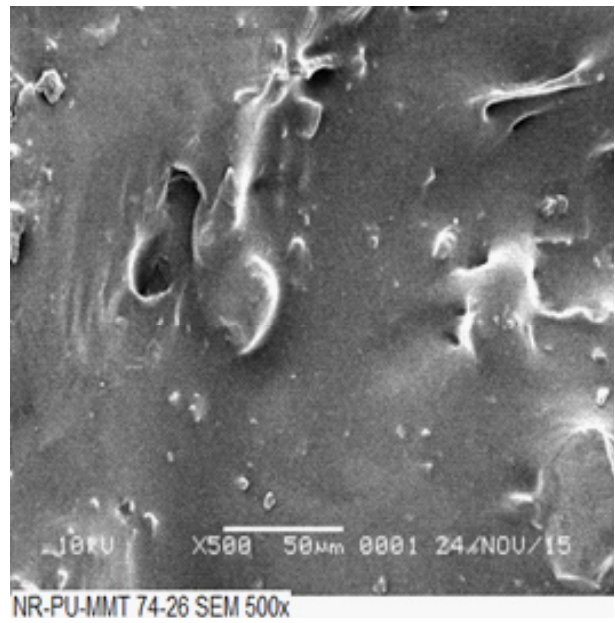

Fig. 6: SEM image of IPN composite : Montmorillonit (74 : 26) properties. It may be caused compatible occurs at IPN composite. In contrast, too much amount of montmorillonit will be disrupt compatibility of all matrix components thereby the mechanic properties will decrease.

\section{DSC Analysis}

DSC data of IPN PU-NR composite is shown in Figure 8.

Figure 8 is thermo gram of IPN NR - PU composite. DSC thermo grams will give information about transition glass ( $\mathrm{Tg})$, melting point $(\mathrm{Tm})$, and

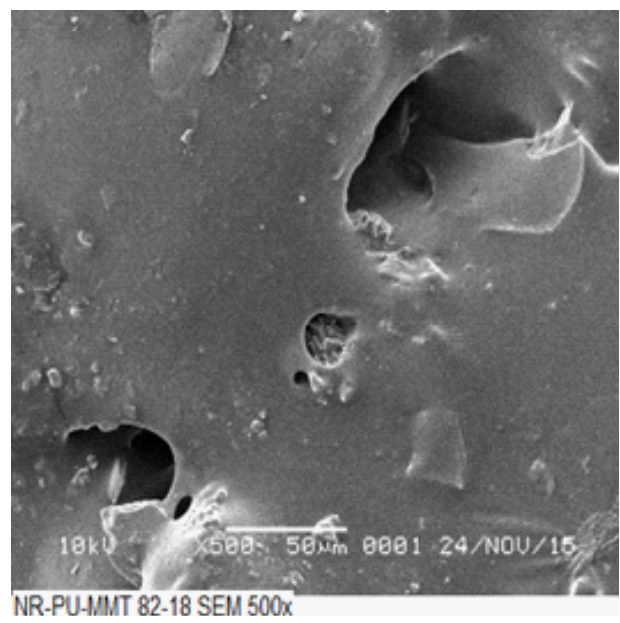

Fig. 7: SEM image of IPN Composite : Montmorillonit (82: 18)

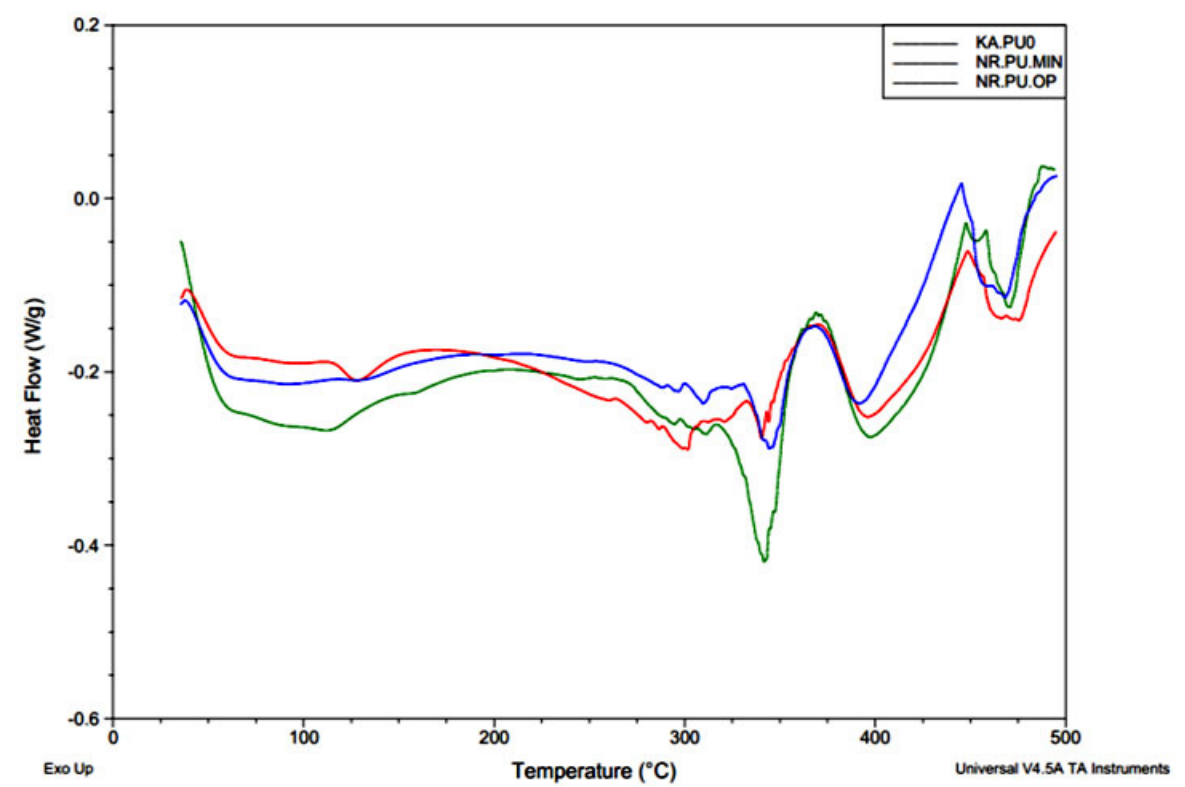

Fig. 8: DSC data of IPN PU-NR Composite 


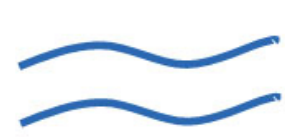

Natural Rubber (NR)

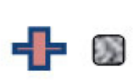

Sulfur

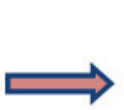

图
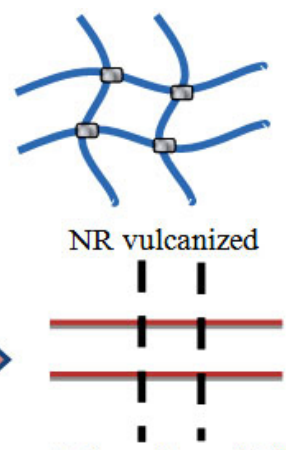

Polyurethane (PU)

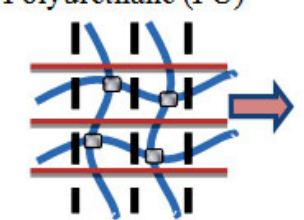

IPN NR-PU

Sulfur

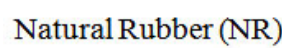

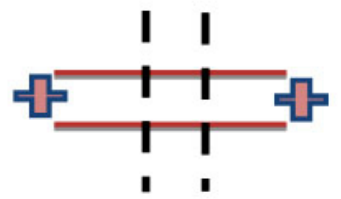

PU

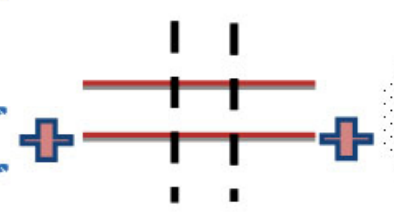

PU

PU

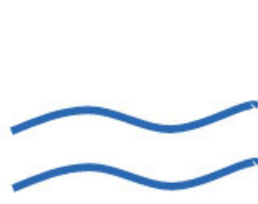

Natural Rubber (NR)

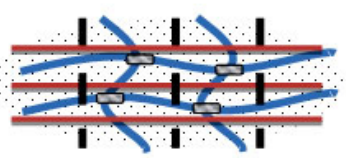

IPN composite

Fig. 9: Mechanism of IPN composite Formation

decomposition temperature. Briefly, thermal analysis of IPN NR : PU composite is shown in Table 3.

Table 11 shows $\mathrm{Tg}$ of NR-PU $\left(108,38^{\circ} \mathrm{C}\right)$, NR-PU-MMT $\left(122,29^{\circ} \mathrm{C}\right)$, and $120^{\circ} \mathrm{C}$ probes that production of IPN composite is similar. NR-PU without montmorillonit has Tg is lower than NR-PU-MMT. It is caused montmorillonit is exist in IPN composite. Indicating IPN NR-PU-MMT composite has $\mathrm{Tg}$ is higher than NR : PU (without MMT).

In addition, Tm of NR-PU : MMT is higher than NR : PU. That is caused IPN exist and it will increase the decomposition temperature of IPN composite.
Shobing (2011) said existence of filler in IPN composite may be increasing thermal stability of NR-PU composite. Transition glass of IPN composite is proportional to homogeny of (heterogenic phase) (Marinovic, S. 2010). Over rate of scanning also will cause Thermal-lag effect (Yulindo, Y. 2008).

In this paper we propose mechanism reaction of IPN NR-PU-MMT composite (Figure 9).

\section{CONCLUSIONS}

1. The best concentration of ratio composite to synthesize of IPN between PolyurethanesNatural Rubber SIR-10 with the addition of Monmorillonit is at a ratio of 74 phr: 26 
phr with a particle size of montmorillonite is average $413.3 \pm 39.3 \mathrm{~nm}$

2. The strain and stress tensile increase with the addition of $20 \mathrm{phr}$ polyurethane at NR: PU (80 : 20 phr)
3. Montmorillonit assists to improve mechanic, morphology and thermal properties of IPN composite.

\section{REFERENCES}

1. Abu bakar, A.. Effect Of Accelerated Wethering On The Mechanical Properties Of Oil Palm Emty Fruit Bunch Filled UPVC Composites. Iranian Polymer Journal. 2005., 14 (7) : 627635.

2. Adnanda, D. N.. Pembuatan dan Karakterisasi Komposit Karet Alam/Montmorillonit Menggunakan CTAB Sebagai Pemodifikasi Organik. FMIPA USU : USU Press. 2015

3. Akram, D.. Synthesis, Characterization And Corrosion Protective Properties OfBoronModiûed Polyurethane From Natural Polyol. Progress In Organic Coatings. 2008., 63., 25-32.

4. Amrollahi, M. 2011. Investigation Of Novel Polyurethane Elastomeric Networks Based On Polybutadiene-ol/Polypropyleneoxide Mixture and Their Structure-Properties Relationship. Materials and Design. 2011.,32 : 3933-3941.

5. Andriyanti, W.. Kajian Metode Vulkanisasi Lateks Karet Alam Bebas Nitrosamin dan Protein Alergen. Yogyakarta : Pusat Teknologi Akselerator dan Proses Bahan. 2010

6. Antonius, P.. Penyediaan Film Mikrokomposit PVC Menggunakan Pemastis Stearin Dengan Pengisi Pati dan Penguat Serat Alam. Tesis Magister. Medan : Program Pasca Sarjana Universitas Sumatera Utara. 2009

7. Bandrup. Hand Book Of Polymer. New York : John Wiley and Sons. 1985.

8. Cahyana, A. 2014. Analisa SEM (Scanning Electron Microscope) Pada Kaca TZN Yang Dikristalkan Sebagian. Prosiding Mathematics and Sciences. ISBN : 978-602-0960-00-5.

9. Dana, J.D.1960. The System Of Mineralogy. Volume 2. Edisi 7. New York : Jhon Wiley and Sons.

10. Ferrer, M.C.C.. Characterisation Of Polyurethane Networks Based On Vegetable Derived Polyol. Polymer. 2008., 49 (2008) :
3279-3287.

11. Franklin, D. 2013. Analisis Sifat Mekanik dan Daya Serap Air Material Komposit Sera Rotan. Yogyakarta : Fakultas Matematika dan Ilmu Pengetahuan Alam Universitas Negeri Yogyakarta.

12. Frederic, V.. Influence Of The Poly(ethylene oxide)/Polybutadiene IPN Morphology On The Ionic Conductivity Of Ionic Liquid. European Polymer Journal. 2013.,49 (2013) : 2670 2679.

13. Hartomo, A. J. 1996. Memahami Polimer dan Perekat. Yogyakarta : Penerbit Andi Offset.

14. Hentschel, T.. Kinetics Of The Molar Mass Decrease In A Polyurethane Melt: A Rheological Study. Polymer. 2001.,42 (2001) : 3195-3203.

15. Hepburn, C.. Polyurethane Elastomer. Second Edition. New York : Elsevier Applied Science. 1991

16. Hummel, D. O.. Infrared Spectra Polymer In Medium and Long Wave Length Region. London : John Wiley and Sons. 1985

17. Irawati, F. Pengaruh Ukuran Serbuk Tempurung Kelapa Sebagai Pengisi Komposit Poliester Tak Jenuh Terhadap Sifat Mekanik dan Penyerapan Air. Jurusan Teknik Kimia USU. 2013. 2, 4 (2013).

18. Jacob, J. 2010. Main Chain And Segmental Dynamics Of Semi Interpenetrating Polymer Networks Based On Polyisoprene And Poly(methyl methacrylate). Polymer. 2010.,51 2390-2402.

19. Laurent, J. G. Soft and Fexible Interpenetrating Polymer Networks Hosting Electroreûective Poly(3,4-ethylene dioxythiophene). Solar Energy Materials \& Solar Cells. 2014., 12., 33-42.

20. Marinovic, S.. The Inûuence Of Different Components On Interpenetrating Polymer Network's (IPN's) Characteristics as 
Automotive Top Coats. Progress in Organic Coatings. 2010.,68 .,293-298.

21. Misra, A.. Swelling Equilibrium Of Dentin Adhesive Polymers Formed On The WaterAdhesive Phase Boundary: Experiments And Micromechanical Model. Acta Biomaterialia. 2014., 10 .,330-342.

22. Morton, M.. Rubber Technology. Third Edition. New York : Van Nostrand Reinhold. 1987

23. Nicolas, F. Electro-Active Interpenetrating Polymer Networks Actuators and Strain Sensors : Fabrication, Position Control and Sensing Properties. Sensorsand Actuators B. 2014. 193 (2014) : 82-88.

24. Odian, G.. Principles Of Polymerization. Fourth Edition. New Jersey : John Wiley \& Sons, Inc. 2004

25. Ompusunggu, M. Pengawetan Bahan Olah Lateks Kebun. Warta Perkaretan. Medan : Pusat Penelitian Perkebunan. 1987.

26. Pal, K.. Effect Of ûllers On Morphological And Wear Characteristics Of NR/HSR

Blends With E-Glass ûber. Material and Design. 2012., 35 (2012) : 863-872.

27. Ramos, B.G.Z. 2006. Polyurethane Nanoparticles From A Natural Polyol Via Miniemulsion Technique. Polymer. 47 (2006) : 8080-8087.

28. Rohaeti, E. Kajian Tentang SintesisPoliuretan dan Karakterisasinya. Yogyakarta :

Fakultas Matematika dan IImu Pengetahuan Alam Universitas Negeri Yogyakarta. 2005.

29. Rohaeti, E.. Analisis Sifat Termal Poliuretan Berbasis Minyak Jarak dan Toluena Diisosianat Dengan DTA dan TGA. Yogyakarta : Fakultas Matematika dan IImu Pengetahuan Alam Universitas Negeri Yogyakarta. 2011

30. Rosado, E.D.. Thermal Degradation Of Urethane Modiûed Polyisocyanurate Foamsbased On Aliphatic And Aromatic Polyester Polyol. Polymer Degradation and Stability. 2002., 78 (2002) : 1-5.

31. Rusdi, R.. Karakteristik Matriks Termoplastik Polietilena Terplastis Poligliserol Asetat. Tesis Magister. Medan : Program Pasca Sarjana Universitas Sumatera Utara. 2008

32. Saelao, J. Influence Of Styrene on Grafting Efficiency Of Maleic Anhydride Onto Natural Rubber. Bangkok : Department Of Chemistry, Faculty Of Science, Mohidol
University. 2004.

33. Savetina, S.. Kekuatan Tarik Komposit Poliester Berpenguat Partikel Kayu Jati, Merawan dan Meranti Merah. Jurnal Mechanical., 2013 .,4. 1.

34. Septiari, I.. Pembuatan Papan Partikel Dari Limbah Plastik Polyprophylene (PP) dan Tangkai Bambu. Singaraja. E-Journal Kimia Visvitalis : 2014.,2 .,1 Tahun 2014.

35. Shoubing, C.. Hydroxy-Terminated Liquid Nitrile Rubber Modiûed Castor Oil Based Polyurethane/Epoxy IPN Composites : Damping, Thermal and Mechanical Properties. Polymer Testing. 2011.,30 (2011) : 726-731.

36. Srilekha, S.D.. Exposure Of Natural Rubber to Personal Lubricants-Swelling and Stress

Relaxation As Potential Indicators Of Reduced Seal Integrity Of Non-Lubricated Male Condoms. Milwaukee : Biomedical Engineering, Marquette University. 2014

37. Stevens, M. P.. Kimia Polimer. Cetakan Kedua. Jakarta : Pradnya Paramita. 2007

38. Tamrin. Penyediaan dan Pencirian Polimer Jaringan Saling Menembus Antara Getah Asli dan Poliuretana. Malaysia : Universiti Teknologi Malaysia. 1997.

39. Tatachiwin, L., Sakdapipanich, J., Ute, K., Kitayama, T., Tanaka, Y. Structural Characterization Of Terminal Group Of Natural Rubber 2 : Decomposition Of Branch-points By Phospolipase And Chemical Treatments. Biomacro-molecules. 2005. 6. 1858-1863.

40. Tim Penulis Penebar Swadaya. 1992. Karet : Strategi Pemasaran Tahun 2000 Budidaya dan Pengolahannya. Jakarta : Penebar Swadaya.

41. Treloar, L.R.G. The Physics Of Rubber Elasticity. London : Oxford University Press. 1958.

42. Triwulandari, E.. Studi polimerisasi Antarmuka Terhadap Distribusi Ukuran Partikel Mikrokapsul Poliuretan Berbasis Gliserol. Tesis Magister. Depok : Universitas Indonesia. 2012

43. Vivek, J. D. Synthesis and Characterization Of Interpenetrating Polymer Networks From Transesteriûed Castor Oil Based Polyurethane and Polystyrene. Journal of Saudi Chemical Society. Gujarat : Sardar Patel University. 2013. 
44. Wake, W. C.. Synthetic Adhesive and Sealants. New York : John Wiley and Sons. 1987

45. Wirjosentono, B.. Analisis dan Karakterisasi Polimer. Medan : USU-Press. 1995

46. Xianwu, Z.. Synthesis And Properties Of Polyurethane Foams Prepared From Heavy Oil Modiûed By Polyols With 4,4'-MethyleneDiphenylene Isocyanate (MDI). Bioresource Technology. 2012., 114 (2012) : 654-657.
47. Yulindo, Y.. Migrasi Dioktil Ftalat dan Etilen Glikol ke Dalam Struktur Poliuretan Dengan Pemanjangan Rantai Diamina Aromatik dan Pengaruhnya Terhadap Kinerja Material. [Tesis]. Jakarta : Universitas Indonesia. 2008

48. Zhang, L.. Substituting Soybean Oil-Based Polyol Into Polyurethane ûexible Foams. Polymer. 2007.,48 (2007) : 6656-6676. 